\title{
A computable general equilibrium analysis of environmental tax reform in Japan with a forward-looking dynamic model
}

\author{
Shiro Takeda ${ }^{1}\left[\right.$ ] Toshi H. Arimura ${ }^{2}$
}

Received: 15 May 2020 / Accepted: 3 January 2021 / Published online: 29 January 2021

(c) The Author(s) 2021

\begin{abstract}
The Japanese government plans to reduce greenhouse gas emissions by $80 \%$ by 2050 . However, it is not yet clear which policy measures the government will adopt to achieve this goal. In this regard, environmental tax reform, which is the combination of carbon regulation and the reduction of existing distortionary taxes, has attracted much attention. This paper examines the effects of an environmental tax reform in Japan. Using a dynamic computable general equilibrium (CGE) model, we analyze the quantitative impacts of an environmental tax reform and clarify which types of environmental tax reform are the most desirable. In the simulation, we introduce a carbon tax and consider the following four scenarios for the use of the carbon tax revenue: (1) a lump-sum rebate to the household, (2) a cut in income taxes, (3) a cut in corporate taxes and (4) a cut in consumption taxes. The first scenario is a pure carbon tax, and the other three scenarios are types of environmental tax reform. Our CGE simulation shows that (1) environmental tax reform tends to generate more desirable impacts than the pure carbon tax and that (2) the strong double dividend is obtained in some cases. In particular, we show that a cut in corporate taxes leads to the most desirable policy in terms of GDP and national income.
\end{abstract}

Keywords Carbon tax $\cdot$ Environmental tax reform $\cdot$ Double dividend $\cdot$ Computable general equilibrium $\cdot$ Climate change $\cdot$ Tax interaction effects $\cdot$ Paris agreement

\section{Introduction}

The Paris Agreement gave momentum to many countries' long-term commitments to reduce greenhouse gases (GHGs). The Japanese government plans to reduce GHG emissions by $80 \%$ by 2050 . However, it is not yet clear which policy measures the government will adopt to meet this target. The choice of policy measures influences the economic burden of emission regulation. Therefore, the government has been careful in designing policy measures.

Handledby Masa Sugiyama, University of Tokyo, Japan.

Shiro Takeda

shiro.takeda@gmail.com

Toshi H. Arimura

arimura@waseda.jp

1 Kyoto Sangyo University, Motoyama, Kamigamo, Kita-Ku, Kyoto City 603-8555, Japan

2 Waseda University, 1-6-1 Nishiwaseda Shinjuku-ku, Tokyo 169-8050, Japan
To reduce the economic burden of GHG regulation, it is desirable and reasonable to use efficient policy measures. From that perspective, it is natural to adopt carbon pricing, i.e., either carbon taxes or emissions trading schemes (ETSs). In Japan, however, ETSs have been introduced only at the local level in Tokyo (Arimura and Abe 2020) and Saitama (Hamamoto 2020). Furthermore, the national government introduced a very low carbon tax of 289 yen per ton (Ministry of Environment 2012). Carbon pricing has faced opposition from industry stakeholders who prefer a voluntary approach (Arimura et al. 2019).

However, this opposition to the carbon tax could be overcome if revenue from the carbon tax is used wisely. If the government implements environmental tax reform, which is the combination of a carbon tax and a reduction in existing distortionary taxes, Japan may achieve both economic growth (or improvement of economics welfare) and emission reduction. This is known as the double dividend of the carbon tax (Bovenberg and Goulder 2002). Although environmental regulation is often considered to be a burden for economies and thus difficult to introduce in many countries, 
the revenue recycling of environmental taxes is expected to mitigate this problem by improving economic efficiency with the reduction of distortionary taxes. For example, if the government uses a carbon tax revenue to reduce corporate taxes, investment will increase. If the labor tax is reduced by revenue recycling, the labor supply will increase. If the economic improvement due to the revenue recycling is strong enough, there are possibilities for economic growth (or improved welfare) alongside GHG emission reduction.

The revenue recycling of the carbon tax, however, may not always lead to economic growth for two reasons. First, if the reduction of economic activities due to carbon pricing is greater than the expansion of economic activities from tax reduction, gross domestic product (GDP) will decrease. Second, if the tax-interaction effect (Bovenberg and Goulder 2002) of the carbon tax is large enough, economic growth under carbon pricing will be difficult. Even before a carbon tax is introduced, economies face various distortionary taxes, such as corporate taxes or income taxes. When a carbon tax is added to these distortionary taxes, the deadweight loss due to the existing tax may become even larger. Thus, the benefit of revenue recycling must be large enough to achieve economic growth under carbon pricing. Since the environmental tax reform has diverse and complex effects on the economy, it is difficult to theoretically predict whether a double divided arises or not. To examine the validity of this hypothesis, we must conduct a numerical simulation.

Previous literature has examined the possibility of double dividend quantitatively. Saveyn et al. (2011) developed a computable general equilibrium (CGE) model for the EU and found a double dividend when permit revenues are used to reduce employees' social security contribution. Developing a dynamic CGE model for the US economy, Carbone et al. (2013) found a double dividend with the revenue recycling of capital taxes (i.e., corporate taxes or personal income taxes on interest, dividends, or capital gains). Jorgenson et al. (2013) also found a double dividend when carbon tax revenues were used to reduce capital taxes for the US economy. Constructing a dynamic CGE model for Portugal, Pereira et al. (2016) showed a double dividend when carbon tax revenues were used for the reduction in personal income taxes and social security contribution. Freire-González (2017) conducted a comprehensive literature review of the double dividend.

A few studies examined the double dividend for the Japanese economy. Takeda (2007) assessed the possibility of a double dividend using revenue recycling for corporate taxes with a dynamic CGE model. Using a macroeconometric model, Lee et al. (2016) examined the double dividend for the Japanese economy. These studies provided useful information about climate change policy in Japan. However, they have shortcomings. First, Takeda (2007) only examined a mild reduction target of 1995 levels that was discussed at that time. Furthermore, he did not consider carbon capture sequestration (CCS) or renewable energies, which are expected to be important options for achieving an $80 \%$ reduction in GHGs in the future. On the other hand, Lee et al. (2016) examined the environmental tax reform of consumption taxes, social security payments and income taxes but not corporate taxes. Thus, no studies have examined the possibility of double dividend, including the reform of corporate taxes, for the long-term emission reduction goal for 2050 .

In this paper, using a dynamic CGE model, we analyze the quantitative impacts of environmental tax reforms and clarify which types of environmental tax reforms are the most desirable. Specifically, we simulated three types of environmental tax reforms depending on the types of existing taxes as the target of revenue recycling: (1) income taxes, (2) corporate taxes and (3) consumption taxes. These three taxes accounted for $77 \%$ of the total national tax revenues in 2016, which indicates that they are the main tax instruments in Japan. One notable feature of our analysis is that we consider CCS activity and renewable energies, which were not considered in Takeda (2007). We do so because the Japanese government believes that CCS and renewable energies are essential for achieving an $80 \%$ reduction in GHG emissions. ${ }^{1}$

We show that the revenue recycling of the carbon tax can lead to economic growth (increase in GDP) in 2030 in the case of the Japanese economy. This shows that the Japanese economy can achieve economic growth while reducing GHG emissions, at least in 2030.

\section{Methods and data}

\section{Overview of the model}

We provide simulations based on a CGE model. In this section, we explain the model and data used for the simulations. The structure of the model is basically the same as that of Takeda (2007), although we make some adjustments. Our model is relatively simple, but we cannot provide a full description of the model due to space limitations. For the algebraic representation of the model, see the supplementary material. $^{2}$

\footnotetext{
${ }^{1}$ If Japan were to reduce GHGs by $80 \%$ without relying on CCS and renewable energies, the carbon tax rate required would be extremely high. Thus, the government recognizes CCS and renewable energies as essential policy options.

2 The full model description is provided in the supplementary material. In addition, the simulation programs are available from the authors upon request. Complete and accurate information about the model structure and the simulation setting can be obtained by reading the program code.
} 
Table 1 List of goods and sectors

\begin{tabular}{llll}
\hline Goods & Sectors & Goods & Sectors \\
\hline Agriculture, forestry and fishery & & Coke & Coal products \\
Coal & Fossil fuels & Other coal products & Construction \\
Crude oil & & Electricity & Electricity (fossil fuel) \\
Natural gas & & & Electricity (nuclear) \\
Non-energy intensive sectors & & & Electricity (hydro) \\
Energy intensive sectors & Petroleum products & Gas and heat supply & Medical, health care and welfare \\
Gasoline & & Railway transport & \\
Jet fuel oils & & Road transport (passenger) & \\
Kerosene & & Road transport (freight) \\
Light oils & & Water transport \\
Heavy oils & & Air transport \\
Naphtha & Other services & \\
LPG & & & \\
Other petroleum refinery products & &
\end{tabular}

Our model is a single country model for Japan that divides the economy into 26 goods and 18 sectors, as listed in Table 1. Basically, one sector produces one good, but some sectors produce multiple goods, and some goods are produced by multiple sectors. For example, the "petroleum products" sector produces eight petroleum goods, and "electricity" is produced by multiple electricity sectors. Thus, the number of goods does not coincide with that of sectors. The model is a forward-looking dynamic model that covers the years 2011 to 2050 . We treat five years as one period and solve the model for every five years to 2050 . The model includes three types of agents: a representative household, firms and the government. We assume that all markets in the model are perfectly competitive and that all agents behave as price takers. The basic structure of the model is depicted in Fig. 1.

\section{Production side}

Firms produce goods with constant-returns-to-scale technology using primary factors and intermediate inputs. The primary factors are labor, capital stock, land and resources. Land is a specific factor used only in the "agriculture, forestry and fishery" sector. Similarly, resources are specific to the "fossil fuels" and electricity sectors. ${ }^{3}$

The production technology in each sector is represented by a constant elasticity of substitution (CES) production function. To consider the differences in the production technologies of goods and services with completely different properties, we divide the production sectors into the

\footnotetext{
3 The sector specific resource factor for a sector is only used in that sector and cannot move to other sectors.
}

following five types: (1) general sectors, (2) "agriculture, forestry and fishery" sector, (3) "fossil fuels" sector, (4), electricity sectors, and (5) "petroleum products", "coal products" and "gas and heat" sectors. The general sectors include all sectors not included in sectors 2-5. We assume different production functions for the different types of sectors. To specify the production functions, we mainly refer to the models used in the MIT EPPA model (Paltsev et al., 2005) and Takeda et al. (2010). Below, we explain the production structure of each sector.

First, the general sectors have the CES production function shown in Fig. 2. The tree diagram in the figure represents the structure of the nested CES function, where symbols, such as E_XX, indicate the elasticity of substitution (EOS) values between inputs. In the general sectors, output is produced by the Leontief aggregation of nonenergy intermediate inputs and an energy-primary factor composite (KLE). The energy-primary factor composite is a nested CES function of composite energy and primary factors (capital and labor). Composite energy is the CES aggregation of electricity and other energy composites, which is, in turn, the CES aggregation of all other energy goods. We use this type of nested production structure because we would like to consider the differences in the EOS values of various inputs.

Next, the production function of the "agriculture, forestry and fishery" sector is given by Fig. 3. In "agriculture, forestry and fishery" sector, the primary factor of land plays an important role in production. Thus, we assume a production function that emphasizes the role of land. In this sector, output is produced by the CES aggregation of land and nonland input, where land is the specific primary factor that is used only in this sector. The structure of nonland input is the same as the production tree of the general sectors. This production function implies that the output of this sector is 


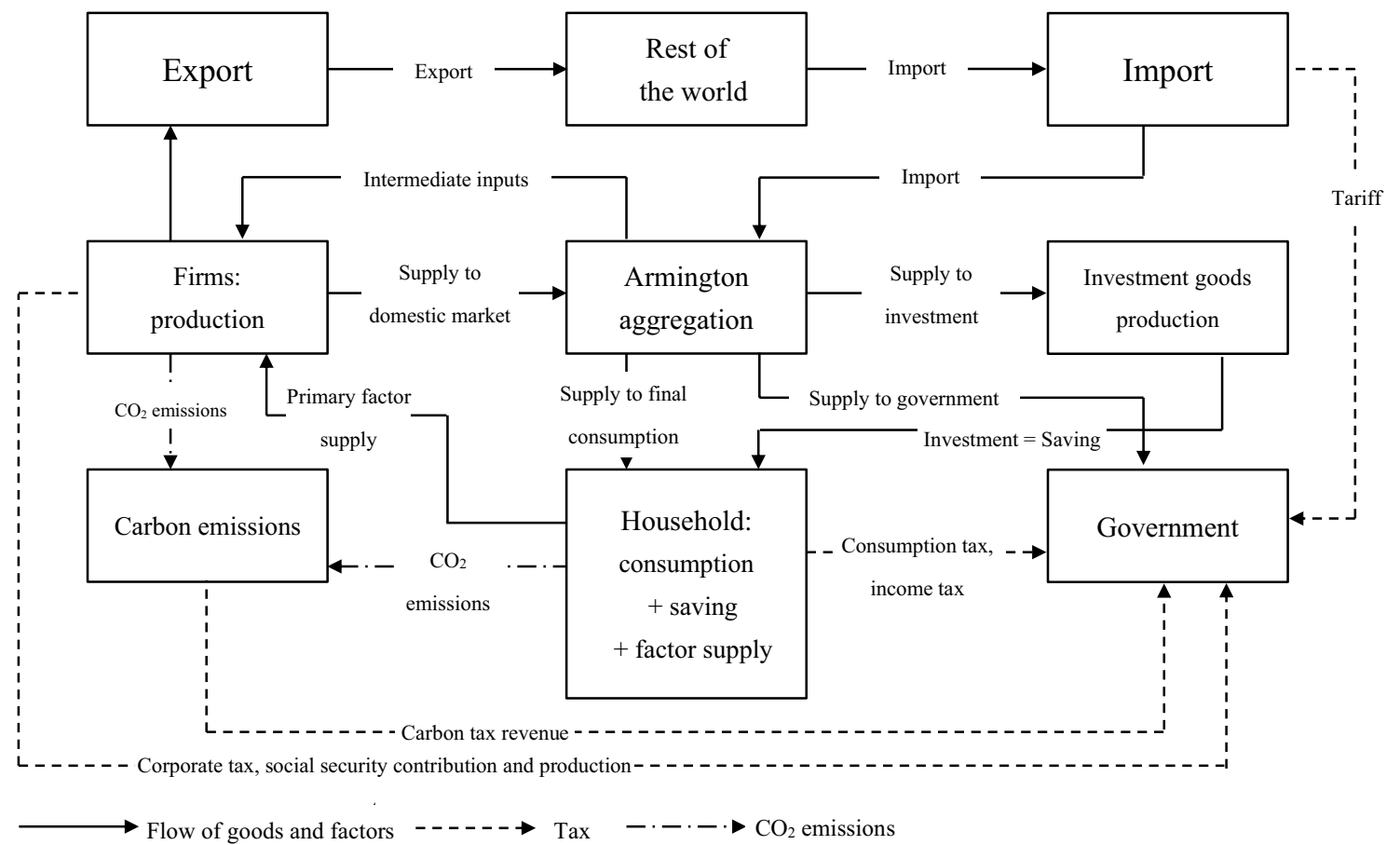

Fig. 1 The basic structure of the model

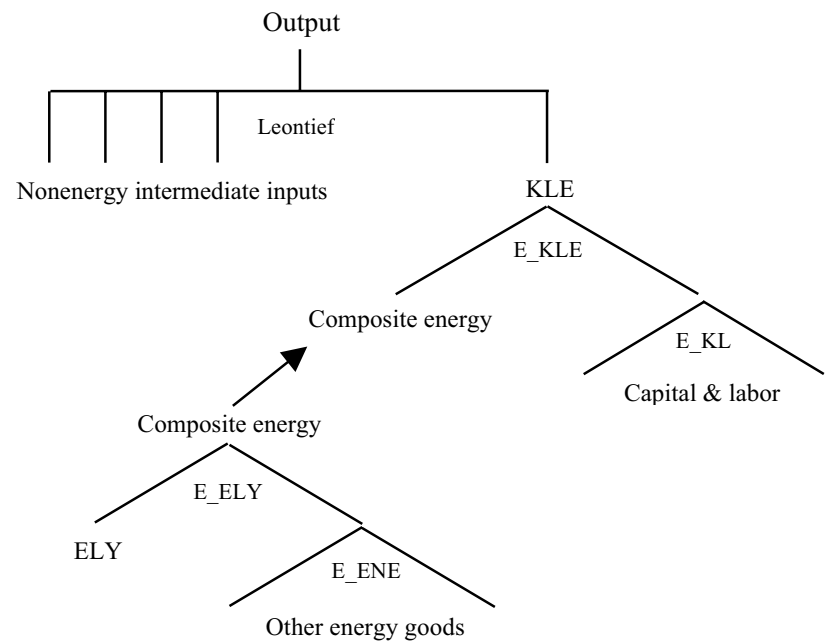

Fig. 2 Production function of the general sectors

strongly restricted by the amount of land. ${ }^{4}$ The benchmark input data of land is derived from GTAP10 data. ${ }^{5}$

\footnotetext{
${ }^{4}$ Due to this restriction, the output of this sector is less likely to change than that of the general sectors.

5 More specifically, we use the GTAP10 factor input share data of the "agriculture, forestry and fishery" sector in Japan. The derived data of the benchmark value of the land input is 916 billion yen.
}

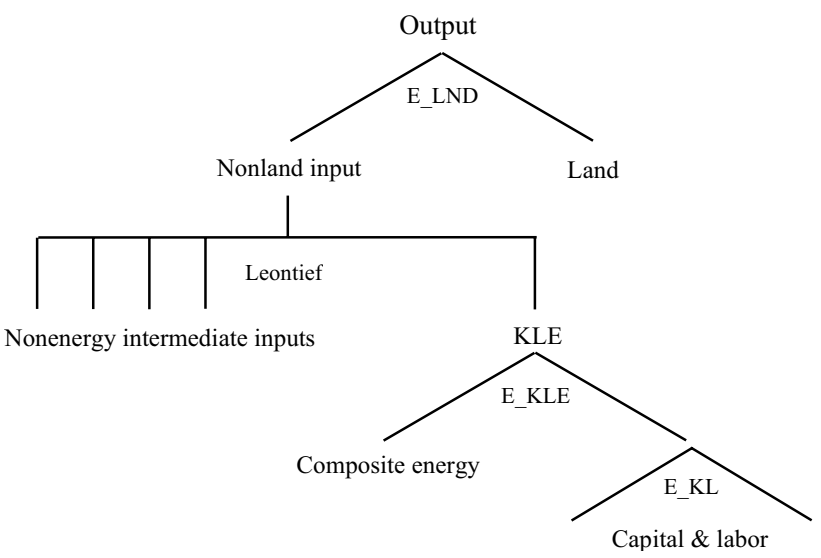

Fig. 3 Production function of the "agriculture, forestry and fishery" sector

The production function of the "fossil fuels" sector is basically the same as that of "agriculture, forestry and fishery" except that "resource" is used instead of land as a sector specific factor. The benchmark resource input data in the "fossil fuels" sector is also derived from the GTAP10 data. ${ }^{6}$

\footnotetext{
6 The derived data of the benchmark value of the resource input is 30.4 billion yen.
} 


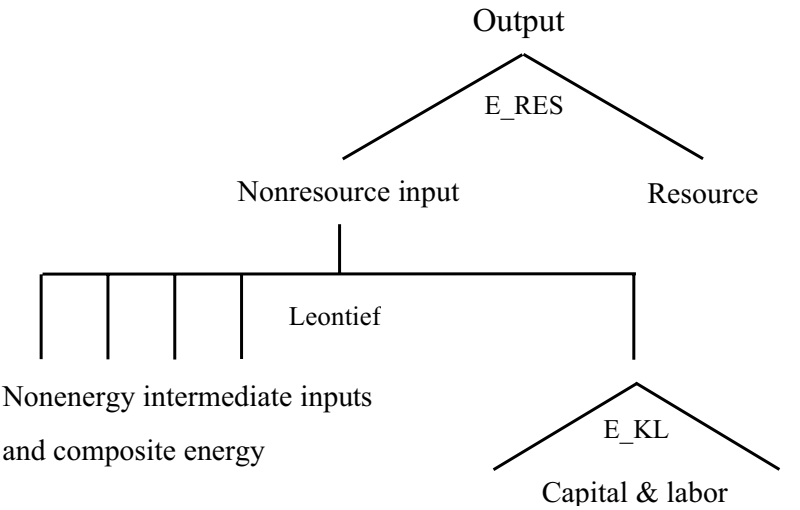

Capital \& labor

Fig. 4 Production function of the electricity sector

The production function of the three electricity sectors has a structure similar to but slightly different from the "agriculture, forestry and fishery" and "fossil fuels" sectors. In the production function of the electricity sectors depicted in Fig. 4, the energy composite enters the second level Leontief nest as a nonenergy intermediate input. We assume this shape for the electricity sectors so that the energy input and the capital-labor composite cannot be substituted in electricity generation by fossil fuels. The electricity sectors use "resource" factors, which are also assumed to be specific to that sector. Although we call it "resource", it does not represent natural resources but represents various nonmarket factors that affect production, and it is used as an instrument for controlling the production level. ${ }^{7}$ The benchmark resource input data for the electricity sectors is derived by assuming that half of the original payment to capital is the payment to the resource input. For the nuclear and hydroelectricity sectors, we assume 0 for E_RES, which means that the amount of electricity produced by nuclear and hydro energy is basically controlled by the sector specific resource amount.

The "petroleum products", "coal products" and "gas and heat" sectors have almost the same production function as the general sectors depicted in Fig. 2, but the method for treating the energy inputs is slightly different. For example, a large amount of "crude oil" is used in the "petroleum products" sector, but almost all of it is used as feedstock,

\footnotetext{
${ }^{7}$ Large electric power plants cannot be built everywhere, as their construction is limited by natural, environmental and political conditions. For example, hydropower plants are constrained by natural conditions. Nuclear power plants are very strongly influenced by political factors. "Resource" factor here represents such constraints. If we assume a specific factor for a sector, the production of that sector is strongly restricted by the amount of that factor because the specific factor cannot be moved from other sectors. The same kind of specific factor is used in electricity sectors in MIT EPPA model Paltsev et al. (2005) and Takeda et al. (2010).
}

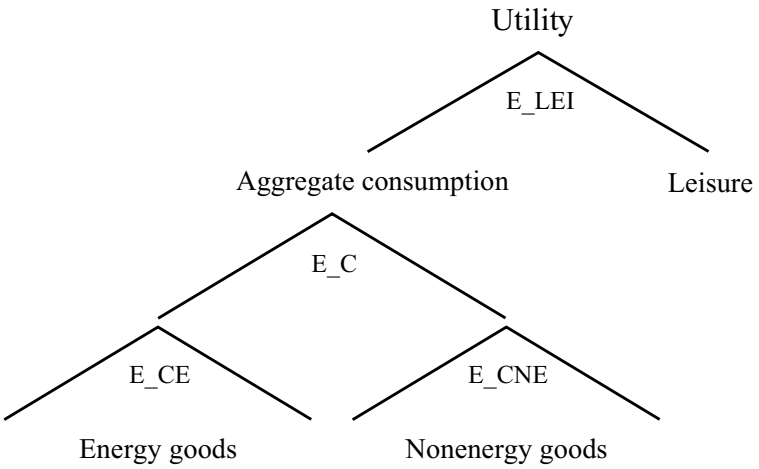

Fig. 5 Period utility function

which means that "crude oil" is used as a material. Thus, it is desirable to treat the oil input in the "petroleum products" sector as a nonenergy input. For this, "crude oil" enters the top Leontief nest in the "petroleum product" sector. A similar treatment is also applied to the "coal" used in the "coal product" sector and the "natural gas" and "LPG" used in the "gas and heat supply" sector.

The production functions explained above include many parameters, in particular, many EOS parameters. The values of the EOS parameters are provided later, in the "Parameters" section. Each sector determines the outputs and inputs needed to maximize their profits. The produced output is allocated to the domestic market or export market. The allocation is conducted through a constant elasticity of transformation (CET) function as in Lofgren et al. (2002) and Takeda (2007).

\section{Demand side}

To represent the demand side of the economy, we assume a microeconomic consumer household. This representative household's utility depends on consumption and leisure. The utility during a period (hereafter, period utility) for the household is represented by the nested CES function in Fig. 5. Aggregate consumption is a CES aggregation of an energy composite and a nonenergy composite with an EOS of E_C. The energy composite is a CES aggregation of energy goods with an EOS of E_CE, and the nonenergy composite is a CES aggregation of nonenergy goods with an EOS of E_CNE. From the period utility in all periods, the lifetime utility of the household is derived as

$u^{L}=\left[\sum_{t=t 0}^{T} \alpha_{t}^{u}\left(u_{t}^{P}\right)^{\frac{\sigma-1}{\sigma}}\right]^{\frac{\sigma}{\sigma-1}}$

where $u^{L}$ is the lifetime utility, $u_{t}^{P}$ is the period utility at period $t$ and $\sigma$ is the intertemporal elasticity of substitution; $t 0$ is the first period and $T$ is the terminal period. The lifetime 
utility function in Eq. (1) is almost the same as those used in Bernstein et al. (1999), Takeda (2007) and Babiker et al. (2009). ${ }^{8}$ The representative household chooses consumption and leisure subject to its lifetime budget constraint to maximize the lifetime utility.

Since the hours of leisure are equal to the total available time minus the hours of work, the leisure decision is equivalent to the labor supply decision. Similarly, since the total budget is allocated to consumption and savings, the consumption decision is equivalent to a savings decision. The representative household provides primary factors to the production sectors and obtains the factor income.

\section{The dynamics of the model}

Our model is a forward-looking dynamic model that assumes a household's dynamic optimizing behavior. The dynamic structure of our model is based on Takeda (2007) except that we do not consider adjustment cost for investment. ${ }^{9}$ Many CGE models used for the analysis of climate change policy, for example, the MIT EPPA model (Chen et al. 2015) and OECD ENV-Linkages model (Chateau et al. 2014), are dynamic models, but they are usually recursive dynamic models. ${ }^{10}$ The recursive dynamic model is a kind of dynamic model that depicts the dynamic path of the economy by solving a myopic or static model iteratively. ${ }^{11}$

An investment is intrinsically an intertemporal resource allocation and the current investment decision is based on the future returns from it. To incorporate this forward-looking nature of investment behavior into the model, we need the forward-looking dynamic model. In fact, macroeconomics, in which the decision regarding investment and saving is one of the main research themes, usually uses the forwardlooking dynamic model.

On the other hand, recursive dynamic models (or static models) cannot capture the forward-looking investment behavior because they do not explicitly deal with future

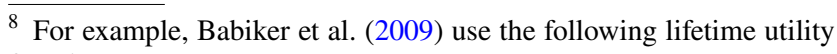
function:

$u^{L}=\left[\sum_{t=0}^{T} \alpha_{t} c_{t}^{\frac{\sigma-1}{\sigma}}\right]^{\frac{\sigma}{\sigma-1}}$

where $c_{t}$ is the consumption at period $t$ and $T$ is their terminal period (year 2050). Although consumption is used instead of period utility, this function has the same form as our lifetime utility function.

9 The structure of the model in Takeda (2007) is explained in detail in its supplementary paper, Takeda (2006).

10 The EPPA model has a forward-looking version; see Babiker et al. (2009).

11 Babiker et al. (2009) use two terms "recursive dynamic model" and "forward-looking dynamic model", respectively, in the same way as we do. In addition to Chen et al. (2015) and Chateau et al. (2014), the following studies use a recursive dynamic CGE model: Capros et al. (2013) and Diao and Thurlow (2012). economic conditions. Actually, many recursive dynamic models determine investment (saving) by the assumption of a constant saving rate. Although some recursive dynamic models use more elaborate approaches, the recursive dynamic model can still only consider current or past economic conditions.

In this research, we assume that corporate tax is a tax on capital income, namely, a tax on return from investment. Therefore, the relationship between corporate tax and investment plays an important role. To capture this relationship appropriately, we employ the forward-looking dynamic model. With the forward-looking dynamic model, the decrease in the corporate tax rate in the future has the effect of stimulating the current investment. The recursive dynamic model or the static model cannot capture this intertemporal effect. This is why we adopt the forward-looking dynamic model.

The dynamic model in this paper is a deterministic model without uncertainty. Therefore, all agents in the model (especially, a representative household) determine their behavior with perfect foresights. When we solve the forward-looking dynamic model, we need to solve all periods simultaneously, which means that the model, particularly the multigoods, multisector model, includes a large number of variables. To reduce the number of variables included in the model, we set one period to five years and solve the model for every five years from 2011 to $2050 .{ }^{12}$ Thus, the benchmark year is 2011 and the terminal year is 2050 . Our model only covers periods until 2050 for the following reasons. First, the climate change policy after 2050 in Japan is not yet clear. Second, we have little information about the energy and carbon technology trends after 2050.

In solving a forward-looking dynamic model with a finite horizon, one problem arises. That is, if no condition is imposed on the terminal adjustment, investment becomes very low as the terminal period approaches because the capital stock existing after the terminal period is worthless. To avoid this problem, we adopt the approach used in Lau et al. (2002). More specifically, we impose the following condition

$\frac{i n v_{T}}{\operatorname{inv}_{T-1}}=\frac{c_{T}}{c_{T-1}}$

where $i n v_{t}$ is the investment in period $t, c_{t}$ is the consumption in period $t$ and $T$ is the terminal period. This condition implies that the rate of increase in investment in the terminal period is equal to that of consumption. With this condition, investment near the terminal period will behave smoothly,

\footnotetext{
12 Strictly speaking, we solve for 2011, 2016, 2021,..,2046, 2051. However, for notational simplification, we use the expression 2011, 2015, 2020,..,2045, 2050.
} 
as in an infinite horizon model. The same approach is used in Bernstein et al. (1999), Takeda (2007) and Babiker et al. (2009).

As Takeda et al. (2010), we assume that the annual depreciation rate for capital is $7 \%$. In addition, we assume that the total time available for the representative household decreases over time at the annual rate of $0.4 \% .{ }^{13}$ Similarly, we assume that the amount of endowments of land and sector specific resources are kept constant over time. By this assumption, the amount of electricity generated by nuclear and hydro energies is kept constant over time. The supply of electricity by hydro energy is strongly constrained by geographical conditions, and it is unlikely that hydro power will change significantly in Japan in the future. With respect to nuclear power in Japan, there is great uncertainty regarding its future use, but the current Japanese government plans to use a certain amount of nuclear as of 2030. Taking account of these situations, we assume that the amount of nuclear and hydro power is constant at the benchmark value over time.

Since our model covers a long time span, the change in technology plays an important role in determining the impacts of climate change policy. For this, we consider growth in total factor productivity (TFP) and autonomous energy efficiency improvement (AEEI). The TFP growth rate and AEEI rate will be explained in the "Simulation scenarios" section.

\section{Government}

The government collects revenue from consumption taxes, income taxes, corporate taxes and other taxes. Then, the government uses this revenue to finance government consumption. We assume that government consumption is constant at the benchmark value over time.

In the environmental tax reform simulation presented later, we reduce the rates of income tax, corporate tax and consumption tax with the introduction of a carbon tax. Thus, these three taxes are of great importance for our analysis. Although there are other various taxes in Japan, we focus on these three taxes because they are main taxes in Japan tax system. ${ }^{14}$ In this section, we explain how these three taxes are incorporated into the model.

First, the income tax is incorporated into the model as a tax on the labor income of the household. Second, the corporate tax is assumed to be a tax on the return from investment

\footnotetext{
13 We assume that the total time available to the household changes in the same way as the population in Japan. The rate of population change is taken from World Energy Outlook 2018.

14 As explained in "Introduction", revenues from three taxes account for $77 \%$ in total national tax revenues in 2016.
}

(capital stock). Finally, the consumption tax, as its name implies, is a tax on consumption. For all taxes, we derive the benchmark tax rate by dividing tax payments by the tax base in the benchmark year. For example, the benchmark income tax rate is derived according to the following formula: income tax rate $=$ value of income tax/value of labor income. This means that all the tax rates in our model are average tax rates. For tax data in the benchmark year 2011, we use the data in "Ministry of Finance statistics monthly No. 722" (Policy Research Institute 2012). ${ }^{15}$ The derived benchmark tax rates for income tax, corporate tax and consumption tax are $5.7 \%, 4.9 \%$ and $3.6 \%$, respectively. Note that the derived consumption tax rate is lower than the actual rate (the consumption tax rate in 2011 was 5\% in Japan). There are many possible reasons for this discrepancy, for example, some goods and service are exempt from the consumption tax. ${ }^{16}$ The fact that the tax rates of income tax, corporate tax and consumption tax are derived from the tax data of Japan means that the taxes in our model are not just numerical examples but reflect the actual Japanese tax system. ${ }^{17}$ All the tax rates in the model are kept constant in the simulation except when we consider environmental tax reform. $^{18}$

\section{International trade}

Our model focuses only on Japan, but we need to consider international trade in goods and services. To incorporate international trade, as in Takeda (2007), we assume that Japan is a small country, which means that the terms of trade in Japan are constant. We assume that the foreign exchange rate is adjusted so that the trade balance is kept constant at the benchmark level. ${ }^{19}$ As with other CGE models, we use the Armington assumption (Armington 1969), which means that domestic goods and imported goods are imperfect substitutes and are aggregated through a CES function.

\footnotetext{
15 The values of income tax, corporate tax and consumption tax in 2011 are 13.4 trillion yen, 8.8 trillion yen and 10.2 trillion yen, respectively.

16 We set $0 \%$ to the consumption tax on "medical, health care and welfare" because it is exempted. However, we do not consider exemptions of other goods and services. The other reason may be an exemption for small businesses.

17 However, the specification of taxes in our model has some problems that need to be improved. We mention these problems in the "conclusions" section.

18 The only exception is the consumption tax rate. Even when we do not consider environmental tax reform, we change the baseline consumption tax rate because it is increased in 2014 and 2019.

19 The benchmark value of trade surplus is 4.7 trillion yen, which is derived from the benchmark data (input-output table).
} 


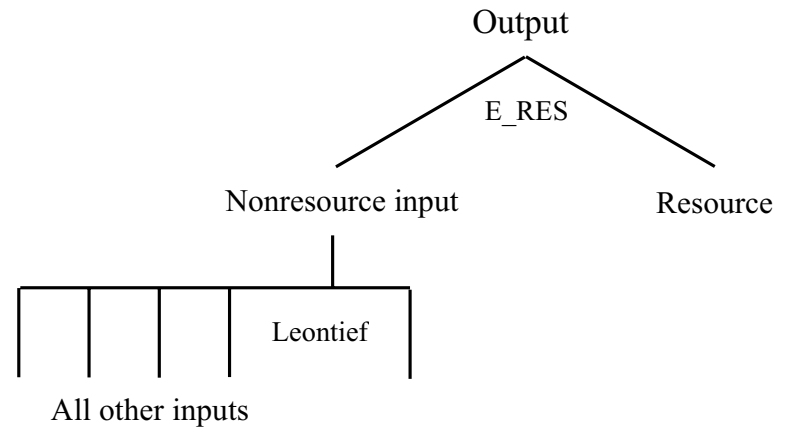

Fig. 6 Production function of the renewable energy electricity sector

\section{Carbon tax}

In the later simulation, we use a carbon tax to regulate $\mathrm{CO}_{2}$ emissions. The carbon tax is a tax based on the amount of $\mathrm{CO}_{2}$ from fossil fuels. Thus, let $p_{i}$ be the original price of fossil fuel $i, t^{\mathrm{CO} 2}$ be the carbon tax rate, and $\delta_{i}$ be the carbon coefficient (the amount of $\mathrm{CO}_{2}$ per unit of fossil fuel $i$ ). Then, the user price of fossil fuel is given by ${ }^{20}$

$p_{i}^{A}=p_{i}+t^{\mathrm{CO} 2} \delta_{i}$

In the simulation, we set the path of $\mathrm{CO}_{2}$ emissions exogenously, and the carbon tax rate is determined endogenously so that the $\mathrm{CO}_{2}$ emissions derived from the model are equal to the target level. This means that carbon tax level changes over time. More specifically, as the reduction rate in $\mathrm{CO}_{2}$ increases over time, the required level of carbon tax also increases. We assume the exogenous path of $\mathrm{CO}_{2}$ emissions because the climate change policy in Japan usually uses the $\mathrm{CO}_{2}$ emissions level as the policy target. The introduction of a carbon tax generates additional tax revenue. The use of a carbon tax revenue is discussed in a later section.

\section{Renewable energy and CCS}

New technology and energy play important roles in the long-term analysis of climate change policy. Specifically, as explained in the introduction, renewable energy and CCS are regarded as essential policy measures to mitigate climate change. Thus, we incorporate these two factors into our model.

First, in addition to electricity generated by conventional energy (fossil fuel, nuclear and hydropower), we add the electricity generated by renewable energy. Like the

\footnotetext{
${ }^{20}$ Strictly speaking, the user price of fossil fuel is distinguished according to its user (sectors and the household).
}

conventional electricity sectors, this renewable electricity sector generates electricity using various production inputs, but fossil fuels are not used and, thus, $\mathrm{CO}_{2}$ is not emitted.

Figure 6 shows the production function of the renewable energy electricity sector. Since there is no information regarding the production structure of this sector in the benchmark data (input-output table), we must specify the production function by other data. To specify the production function, we use benchmark the "input cost share" data and "markup factor". The benchmark input cost share indicates the benchmark share of each input in the total cost. The markup factor specifies the cost of the renewable energy electricity relative to the existing technology. We use this information to specify the production function of the renewable energy electricity sector. The same approach is used in, for example, Takeda et al. (2010) and the MIT EPPA model (Paltsev et al. 2005).

We can obtain the benchmark input cost share data from the estimates provided by the Power Generation Cost Verification Working Group. ${ }^{21}$ For example, in the total cost of generating electricity by solar power, "policy cost", "operating cost including labor cost", and "capital cost" account for $13.6 \%, 12.4 \%$ and $74.0 \%$, respectively. ${ }^{22}$ Since the classification of inputs used in the above estimate does not match the classification of goods in our model, we cannot use the estimate directly in our model. However, we do not have another appropriate estimate. Therefore, from this estimate, we assume the benchmark cost share of inputs for the renewable energy electricity sector of our model as follows: "other services" $=10 \%$, "labor" $=10 \%$, "capital" $=40$, "resource" $=40 \%$. As in the conventional electricity sectors, we assume a sector specific resource input, which is used as the factor controlling the supply of electricity by renewable energies.

In addition, we need to determine the values of the markup factor and the amount of the sector specific resource factor. To do so, we use the World Energy Outlook (WEO) 2018 (International Energy Agency 2018). More specifically, we determine the values of two parameters so that the supply of electricity from renewable energies is close to the value predicted in WEO 2018. ${ }^{23}$

Since we assume that the cost of electricity generated by renewables is higher than that of the conventional electricity sectors (that is, the markup factor is assumed to be high), the

\footnotetext{
21 The data are available from https://www.enecho.meti.go.jp/commi ttee/council/basic_policy_subcommittee/.

22 This estimate is derived from the 2014 model plant scenario.

23 As will be explained in a later section, the BAU equilibrium is used to replicate the "current policies scenario" in World Energy Outlook 2018. In the WEO scenario, the volume of electricity by renewable resources (except hydro) reaches $175 \mathrm{TWh}$ in 2040. We use this value for the target supply value.
} 


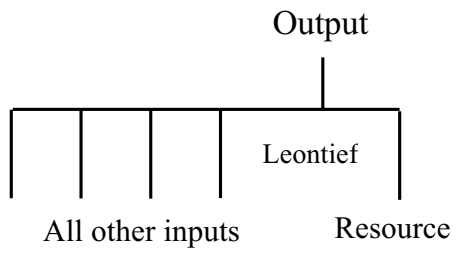

Fig. 7 Production function of CCS activity

supply of electricity generated by renewables is small in the early period and increases gradually as the $\mathrm{CO}_{2}$ regulation is strengthened and the price of electricity rises. Because there is huge uncertainty in the cost and limit of renewable energy, we conduct the sensitivity analysis of the assumption regarding the amount of renewable energy.

Next, we explain the approach for modeling the CCS activity. CCS is usually combined with coal-fired electricity generation, but for simplicity, we assume that the CCS activity is conducted by an independent sector. The production function of the CCS sector is given by Fig. 7, which shows that the CCS activity is supplied under the Leontief production function with fixed coefficients. Since we have no appropriate information for specifying the parameters in the production function, we use the cost share information of the renewable energy electricity sector for the CCS activity, although this approach is slightly ad hoc. We assume that the sector specific resource input and other inputs are not substitutable because the CCS activity is likely to be strongly restricted by the technological and geographical factors that are embodied in the sector specific resource factor.

We adjust the markup factor so that cost of CCS is close to 10,000 yen per ton, which is taken from the report published by Ministry of the Environment. ${ }^{24}$ This relatively high cost of CCS means that CCS is not supplied in the early periods and the supply of CCS increases as the carbon price rises. We adjust the amount of the sector specific resource so that an upper limit on CCS becomes $180 \mathrm{MtCO}_{2}$ per year, which is taken from the estimate by Akimoto and Sano (2017).

Because there is huge uncertainty about the available amount of CCS, we conduct the sensitivity analysis on the amount of CCS. The existence of CCS means that net $\mathrm{CO}_{2}$ emissions are equal to gross $\mathrm{CO}_{2}$ emissions minus CCS.

\section{Benchmark data}

Any CGE analysis is based on the benchmark data that represent the economy at a certain period. We use Japanese input-output data from 2011 (Ministry of Internal Affairs

\footnotetext{
${ }^{24}$ The following document reports that the average cost of CCS is 10,287 yen/ton. https://www.env.go.jp/earth/ccs/h26_report.html.
}

and Communications Japan 2016) for the benchmark data and aggregate sectors and goods of the original IO data into the sectors and goods in Table 1. For $\mathrm{CO}_{2}$ emissions data, we use 3EID data from 2011 (Center for Global Environmental Research 2018).

\section{Parameters}

The functions appearing in the model include many parameters. The values of the EOS parameters are reported in Table 2, where the symbols indicate the EOS parameters appearing in the figures and the text. The column "Source" indicates the source from which the parameter values are taken. The EOS values are basically taken from the previous CGE studies, but we change some of them slightly to fit our model. Because we have no empirical estimate for E_LND, we assume 0.5 .

\section{Simulation scenarios}

\section{Scenarios}

In the simulation, we consider the five scenarios listed in Table 3. The BAU (business-as-usual) scenario is a reference scenario in which no explicit $\mathrm{CO}_{2}$ regulation (carbon tax) is adopted. We determine some of the exogenous parameters in the model so that the equilibrium in BAU replicates the situation under the "current policies scenario" in the World Energy Outlook 2018 (International Energy Agency 2018). Specifically, we determine rates of TFP growth and AEEI so that values of GDP and $\mathrm{CO}_{2}$ emissions derived from the model replicate those of WEO 2018. In "current policies scenario" in WEO 2018, the average annual growth rate of GDP in Japan is $0.7 \%$. We adjust the TFP growth rate so that the average growth rate of GDP from the model is close to the WEO value. In WEO 2018, the $\mathrm{CO}_{2}$ emissions of Japan in 2040 are approximately $820 \mathrm{MtCO}_{2}$. We adjust the AEEI rate so that the $\mathrm{CO}_{2}$ value from the model is close to this value. The derived annual rates of TFP growth and the AEEI parameter are $1.4 \%$ and $2.4 \%$, respectively.

In the four scenarios other than BAU, we impose a carbon tax to reduce $\mathrm{CO}_{2}$ emissions by $80 \%$ by 2050 . We use 2020 as the benchmark year for the reduction rate. Thus, if the amount of $\mathrm{CO}_{2}$ in 2020 is $800 \mathrm{MtCO}_{2}$, an $80 \%$ reduction means that (net) $\mathrm{CO}_{2}$ must be reduced to $160 \mathrm{MtCO}_{2}$ by 2050 . Since we impose carbon restriction from 2020, a carbon tax will be introduced after from 2020.

The "lump-sum rebate scenario" is the scenario in which carbon tax revenue is rebated to the household in a lump-sum way. This scenario does not change existing tax rates and thus represents the scenario of a pure carbon tax. The other three scenarios are environmental tax 
Table 2 Value of elasticity of substitution parameters

\begin{tabular}{lll}
\hline Symbol & Value & Source \\
\hline E_KLE & 0.4 & Takeda et al. (2010) \\
E_KL & for three conventional electricity sectors & \\
& 1.0 for other sectors & \\
E_ELY & 0.1 for three conventional electricity sectors & \\
& 0.5 for other sectors & \\
E_ENE & 0.5 for three conventional electricity sectors & \\
& 0.3 for transport sectors & \\
E_LND & 1.0 for other sectors & This value is \\
& 0.5 & assumed by \\
E_RES & & authors \\
& 0.1 for electricity (fossil fuel) & Takeda et al. (2010) \\
& 0.0 for electricity (nuclear and hydro) & \\
E_LEI & 0.6 for fossil fuel sectors & \\
E_C & 0.2 for renewable energy electricity & Takeda et al. (2014) \\
E_CE & 0.73 & Takeda et al. (2019) \\
E_CNE & 0.5 & \\
Intertemporal elasticity of substitution & 0.5 & \\
Armington elasticity & 1 & Takeda (2007) \\
Elasticity of transformation & 4 & GTAP data \\
\hline
\end{tabular}

Values of parameters are basically taken from the previous studies. Since value of E_LND is not found in the previous studies, we assume 0.5 for it. We think that value of E_LND has little impacts on simulation results because "agricultural, forestry and fishery" sector only has a small share in Japan
Table 3 List of scenarios

\begin{tabular}{ll}
\hline Scenario & Explanation \\
\hline BAU & $\begin{array}{l}\text { Business As Usual (BAU) scenarios without } \\
\text { carbon tax }\end{array}$ \\
Lump-sum rebate & $\begin{array}{l}\text { Carbon tax + lump-sum rebate to the household } \\
\text { (the pure carbon tax scenario) }\end{array}$ \\
Income tax & Carbon tax + cut in income tax \\
Corporate tax & Carbon tax + cut in corporate tax \\
Consumption tax & Carbon tax + cut in consumption tax \\
\hline
\end{tabular}

In all scenarios with carbon tax, $\mathrm{CO}_{2}$ emissions are reduced by $80 \%$ by 2050

reform scenarios in which the carbon tax replaces the existing taxes. First, the "income tax scenario" is a scenario in which income tax is reduced. The income tax in this model is a tax on the labor income of the household and lowers the incentive to work. The cut in income taxes has the effect of stimulating incentives to work and increasing the labor supply. It leads to an increase in production and generates positive impacts on the economy. The "corporate tax scenario" is a scenario featuring a cut in corporate taxes. Corporate tax in our model is a tax on returns from capital stock and thus suppresses incentives to invest. The cut in corporate taxes increases investment and accelerates the accumulation of capital, leading to an increase in output.
Finally, the "consumption tax scenario" is the scenario of cuts in consumption taxes. During the second half of the 2010s, the consumption tax became the major tax in Japan, and its share of the total tax is the largest. The cut in consumption tax is expected to stimulate consumption demand and thereby production. In the simulation, we compare the results from BAU with those from other scenarios. Specifically, we check how equilibrium, particularly macroeconomic variables, changes from the BAU equilibrium when $\mathrm{CO}_{2}$ regulations are imposed.

\section{Criteria for the double dividend}

Many studies have investigated environmental tax reform and the possibility of the double dividend. Some studies report the existence of the double dividend, and others do not, and there are wide varieties in conclusions (see FreireGonzález 2017). One reason for these diverse conclusions is that different studies use different criteria for judging the existence of the double dividend. Theoretical studies often use "utility" (or equivalent variation, EV) as a criterion for the double dividend (Bovenberg and Goulder 2002), but some use the volume of employment instead (e.g., Bovenberg and van der Ploeg 1998). On the other hand, CGE studies often use GDP and income for the criteria. In addition, when utilizing a dynamic model, there are two types 
of utility that can be used as criteria, i.e., period utility and lifetime utility. ${ }^{25}$ Since these variables move differently, the existence of the double dividend depends on which variable is used as criteria.

From a theoretical point of view, utility may be the most important variable for measuring welfare of the country because GDP is just an index for domestic production and income cannot capture value of leisure. However, utility is not directly observable and thus difficult to use as a policy criterion. Actually, utility is rarely used as a policy evaluation criterion in policy making in Japan. Instead, GDP (or income) has been used as an important policy indicator, and thus, policy makers find the information about policy impacts on GDP very helpful. ${ }^{26}$

Since each criterion has some advantages and disadvantages, we decide to provide multiple criteria for a double dividend. Specifically, we use the following four criteria (variables): real GDP, (national) income, period utility ${ }^{27}$ and lifetime utility. "GDP" is calculated from the expenditure side. ${ }^{28}$ "Income" is the after-tax disposable income of the household that can be used for consumption and saving expenditure. ${ }^{29}$ In explaining the simulation results, we report the change in GDP and income in 2030 and 2050. In addition, we report their discounted sums, which are calculated from the values in all periods $(2011-2050) .{ }^{30}$ Since

\footnotetext{
${ }^{25}$ For example, Takeda (2007) uses lifetime utility for the criterion of the double dividend.

${ }^{26}$ We do not insist that GDP and income are better indicators of welfare. Rather, GDP and income have drawbacks as indicators of household welfare. However, we report impacts on GDP and income because they are used as important policy indicators in actual policy making.

${ }^{27}$ In the CGE analysis, the Hicksian equivalent variation (EV) is used for the policy evaluation. In this model, the positive value of EV in a period is equivalent to the positive change rate in period utility in that period. Therefore, the two indicators are equivalent in terms of their signs.

${ }^{28}$ Real GDP is calculated by the following formula with constant prices in 2011: GDP = consumption + investment + government consumption + export-import.

${ }^{29}$ Income is defined from the expenditure side and expressed as follows:

Income $=\frac{p^{C} C+p^{I} I}{p^{C}}$
}

where $p^{C}$ is price index of consumption, $p^{I}$ is price index of investment goods, $C$ is aggregate consumption and $I$ is aggregated investment.

${ }^{30}$ When calculating lifetime utility and sum of discounted values, we use values in periods covered by our model (that is, from 2011 to 2050). However, some studies also use values after the terminal period. For example, Babiker et al. (2009) use such an approach. We do not consider utility after terminal period because economic situation after 2050 is highly uncertain, and thus we want to avoid including such uncertainties in the calculation. But note that our definition of lifetime utility ignores period utility in the distant future.
Table 4 GDP and $\mathrm{CO}_{2}$ emission in BAU

\begin{tabular}{|c|c|c|c|c|}
\hline & \multicolumn{2}{|l|}{ Level $^{\mathrm{a}}$} & \multicolumn{2}{|c|}{$\begin{array}{l}\text { Annual growth rate } \\
(\%)\end{array}$} \\
\hline & GDP & $\mathrm{CO}_{2}$ & GDP & $\mathrm{CO}_{2}$ \\
\hline 2020 & 545.8 & 952.0 & 0.5 & -1.3 \\
\hline 2025 & 563.1 & 902.7 & 0.6 & -1.1 \\
\hline 2030 & 583.8 & 866.8 & 0.7 & -0.8 \\
\hline 2035 & 607.6 & 840.7 & 0.8 & -0.6 \\
\hline 2040 & 633.9 & 825.4 & 0.9 & -0.4 \\
\hline 2045 & 662.4 & 822.5 & 0.9 & -0.1 \\
\hline 2050 & 693.7 & 821.1 & 0.9 & 0.0 \\
\hline
\end{tabular}

${ }^{\mathrm{a}} \mathrm{GDP}$ is trillion yen, and $\mathrm{CO}_{2}$ is $\mathrm{MtCO}_{2}$

the interest rate in Japan has been very low recently, we use $1 \%$ as a discount rate for calculating the discounted value.

In the discussion of the double dividend hypothesis, there are two types of double dividend, i.e., a "strong double dividend" and a "weak double dividend" (Goulder, 1995). The former indicates the situation where environmental tax reform generates a positive impact on the criterion variable, for example, the increase in GDP when GDP is used as a criterion. The latter double dividend indicates the situation in which environmental tax reform generates better results than the lump-sum rebate of carbon tax revenue. A strong double dividend is the most desirable result, but even a weak double dividend shows environmental tax reform's superiority to the pure carbon tax.

\section{Results}

\section{BAU equilibrium}

We first show the results in the BAU scenario. Table 4 reports GDP and $\mathrm{CO}_{2}$ emissions in the BAU scenario. In BAU, GDP increases at an annual rate of $0.5-0.9 \%$ (the average annual rate is $0.7 \%$ ) and reaches approximately 700 trillion yen in 2050. The growth of GDP is due mainly to capital accumulation and TFP growth. On the other hand, $\mathrm{CO}_{2}$ emissions gradually decrease to approximately 820 $\mathrm{MtCO}_{2}$ in 2050. Although GDP increases and there is no explicit $\mathrm{CO}_{2}$ regulation (carbon tax) in $\mathrm{BAU}, \mathrm{CO}_{2}$ emissions decrease over time because there are energy efficiency improvements by the AEEI parameter and an increase in renewable energy.

Figure 8 shows the path of electricity generation in BAU (TWh). Electricity ultimately decreases in the long run in BAU. In addition, electricity generation by fossil fuels decreases significantly, while electricity generation by renewable energy increases, leading to a decrease in $\mathrm{CO}_{2}$ emissions, as described in the previous paragraph. The levels 


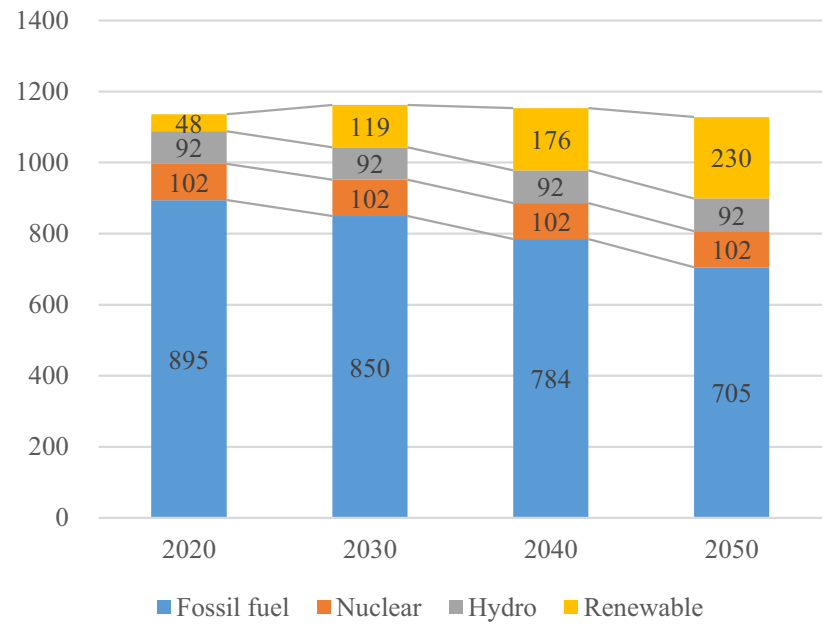

Fig. 8 Electricity generation in BAU (TWh)

Table 5 Tax revenues in BAU (trillion yen)

\begin{tabular}{llll}
\hline & Income tax & Corporate tax & $\begin{array}{l}\text { Con- } \\
\text { sumption } \\
\text { tax }\end{array}$ \\
\hline 2020 & 13.6 & 9.4 & 18.4 \\
2025 & 14.1 & 9.8 & 19.1 \\
2030 & 14.7 & 10.2 & 19.9 \\
2035 & 15.3 & 10.7 & 20.8 \\
2040 & 16.0 & 11.2 & 21.8 \\
2045 & 16.8 & 11.7 & 23.0 \\
2050 & 17.6 & 12.3 & 24.2 \\
\hline
\end{tabular}

of electricity from nuclear power and hydropower are kept constant by the assumption.

Table 5 reports BAU values of revenues from taxes that are reduced in the environmental tax reform scenarios. The rates of all taxes are kept constant, but economic growth in BAU increases revenues from all taxes over time.

\section{Impacts of the carbon tax}

Now, let us examine the impacts of the carbon tax. Table 6 reports $\mathrm{CO}_{2}$ emissions (gross and net emissions), the volume of CCS and the carbon tax rate (yen/per ton) in 2030 and 2050. In BAU, $\mathrm{CO}_{2}$ emissions in 2030 and 2050 are $866.8 \mathrm{MtCO}_{2}$ and $821.1 \mathrm{MtCO}_{2}$, respectively. Under $\mathrm{CO}_{2}$ regulation, net $\mathrm{CO}_{2}$ emissions decrease to $685.4 \mathrm{MtCO}_{2}$ and $190.4 \mathrm{MtCO}_{2}$ in 2030 and 2050, respectively. Note that net $\mathrm{CO}_{2}$ emissions are the same in all the scenarios with carbon tax, but the carbon tax rates differ across scenarios. This is because we set the same path of $\mathrm{CO}_{2}$ emissions in all the scenarios and the carbon tax rates are endogenously adjusted to achieve the emissions target.

The $80 \%$ reduction target means an $80 \%$ reduction from the $2020 \mathrm{CO}_{2}$ level, and the reduction rate from the 2050 level $\left(821.1 \mathrm{MtCO}_{2}\right)$ is slightly smaller (approximately $76.8 \%$ ). Nevertheless, it shows that Japan must reduce a significant amount of $\mathrm{CO}_{2}$ emissions.

$\mathrm{CO}_{2}$ emissions here indicate net $\mathrm{CO}_{2}$ emissions. Because of the existence of CCS activity, gross $\mathrm{CO}_{2}$ emissions do not decrease as much as net $\mathrm{CO}_{2}$ emissions. The amount of CCS in 2050 reaches $180.0 \mathrm{MtCO}_{2}$, which is the upper limit, and thus, gross $\mathrm{CO}_{2}$ emissions are greater than net emissions by $180.0 \mathrm{MtCO}_{2}$.

The significant decrease in $\mathrm{CO}_{2}$ emissions is realized by the carbon tax. The required carbon tax rate in the lumpsum rebate scenario is approximately 8,600 yen in 2030 and 61,000 yen in 2050 . These tax rates are not very different in environmental tax reform scenarios, which shows that a significantly high carbon tax rate is needed to reduce $\mathrm{CO}_{2}$ emissions by $80 \%$. Sugiyama et al. (2020) report carbon prices calculated in various studies on $80 \%$ reduction in Japan. The median of carbon prices in their studies is slightly higher than our estimate, which means that our estimate is comparable to their simulation.

Next, let us observe the impacts on macroeconomic variables. Table 7 reports the percentage change in GDP, income, period utility, lifetime utility, sum of discounted GDP and sum of discounted income from BAU values. GDP, income
Table $6 \mathrm{CO}_{2}$ emissions under the carbon tax

\begin{tabular}{lllllll}
\hline & BAU & Lump-sum rebate & Income tax & Corporate tax & Consumption tax \\
\hline 2030 & $\mathrm{CO}_{2}$ (gross) & 866.8 & 685.4 & 685.4 & 685.4 & 685.4 \\
& $\mathrm{CO}_{2}$ (net) & 866.8 & 685.4 & 685.4 & 685.4 & 685.4 \\
& $\mathrm{CCS}$ & 0.0 & 0.0 & 0.0 & 0.0 & 0.0 \\
& Carbon tax rate (yen/ton) & 0 & 8,564 & 8,796 & 9,423 & 9,069 \\
2050 & $\mathrm{CO}_{2}$ (gross) & 821.1 & 370.4 & 370.4 & 370.4 & 370.4 \\
& $\mathrm{CO}_{2}$ (net) & 821.1 & 190.4 & 190.4 & 190.4 & 190.4 \\
& $\mathrm{CCS}$ & 0.0 & 180.0 & 180.0 & 180.0 & 180.0 \\
Carbon tax rate (yen/ton) & 0 & 60,684 & 62,093 & 65,093 & 62,481 \\
\hline
\end{tabular}

$\mathrm{CO}_{2}$ and $\mathrm{CCS}$ units are $\mathrm{MtCO}_{2}$ 
Table 7 Macroeconomic impacts (\% change from BAU values)

\begin{tabular}{|c|c|c|c|c|c|}
\hline & & $\begin{array}{l}\text { Lump-sum } \\
\text { rebate }\end{array}$ & Income tax & $\begin{array}{l}\text { Corporate } \\
\operatorname{tax}\end{array}$ & $\begin{array}{c}\text { Consumption } \\
\operatorname{tax}\end{array}$ \\
\hline \multirow[t]{3}{*}{2030} & GDP & -0.28 & 0.03 & 0.99 & 0.19 \\
\hline & Income & -0.40 & -0.06 & 1.10 & 0.63 \\
\hline & Period util. & -0.30 & -0.41 & -0.49 & -0.05 \\
\hline \multirow[t]{6}{*}{2050} & GDP & -2.09 & -1.51 & -0.13 & -1.78 \\
\hline & Income & -2.93 & -2.28 & -0.68 & -2.12 \\
\hline & Period util. & -1.95 & -1.93 & -1.69 & -1.77 \\
\hline & Lifetime util. & -0.47 & -0.47 & -0.68 & -0.43 \\
\hline & Sum of discounted GDP & -0.49 & -0.25 & 0.66 & -0.19 \\
\hline & Sum of discounted income & -0.70 & -0.44 & 0.65 & -0.07 \\
\hline
\end{tabular}

All values are percentage change froxxm BAU value. The blue cells indicate a strong double dividend, and the orange cells indicate a weak double dividend

and period utility are reported for two periods, i.e., 2030 and 2050. From these values, we can see whether environmental tax reform generates the double dividend or not.

First, we examine the impacts in 2030. In the lump-sum rebate scenario, all three variables (GDP, income and period utility) decrease with the carbon tax. This is an expected result because the lump-sum rebate scenario represents the pure carbon tax. On the other hand, the three environmental tax reform scenarios increase GDP. This means that there is a strong double dividend from the environmental tax reform in terms of GDP. Similarly, we find a strong double dividend from cuts in corporate tax and consumption tax in terms of income. In addition, we obtained a weak double dividend for income under income tax scenario. These results suggest that an environmental tax reform generally has more desirable impacts than a pure carbon tax in terms of GDP and income. In particular, the cut in corporate tax is the most desirable in terms of GDP and income because it increases the two variables most. On the other hand, in terms of period utility, we found no double dividend for income and corporate tax cut scenarios. Thus, an environmental tax reform is not likely to be desirable in terms of period utility.

Next, let us observe the impacts in 2050. In 2050, we find no strong double dividend for any scenario or criterion, but we find a weak double dividend for all scenarios and criteria. These results in 2050 also show that an environmental tax reform generally has more desirable impacts than a pure carbon tax. In the corporate tax scenario, there is no strong double dividend, but the negative impacts on GDP, income and period utility are significantly reduced from the pure carbon tax scenario. In this sense, corporate tax cut is the most desirable in environmental tax reform scenarios.
Finally, let us observe the lifetime utility, sum of discounted GDP and sum of discounted income, which represent impacts over the entire period. Under the income tax and consumption tax scenarios, we find a weak double dividend in terms of all the criteria. Under the corporate tax scenario, we find a strong double dividend in terms of the sum of discounted GDP and income but find no double dividend in terms of the lifetime utility. These results also show that the environmental tax reform tends to have a more desirable effect than a pure carbon tax, although the cut in corporate tax has undesirable impacts in terms of lifetime utility.

The cuts in income and consumption taxes generate at least a weak double dividend in almost all cases and criteria except period utility in 2030 under the income tax scenario. In addition, the cut in corporate tax tends to generate a strong double dividend in GDP and income. These results suggest that an environmental tax reform generally has more desirable impacts than a pure carbon tax. However, it does not mean that an environmental tax reform is always superior to the pure carbon tax. For example, the cut in corporate tax is not superior to the pure carbon tax in terms of period utility in 2030 and lifetime utility. This ambiguity in results suggest that when designing environmental tax reform, we need to pay attention to which criteria are the most important.

To clarify the mechanism that works for determining impacts on GDP, income and utility, Fig. 9 presents graphs of important variables in the model. All values in the graphs are percentage change from BAU values unless otherwise indicated. Figure 9-e reports "Tax level”. Value in this graph indicates the level of tax reduced in the scenario. For example, INC means the level of income tax (normalized to unity 
a) Carbon tax (1000 yen/ton)

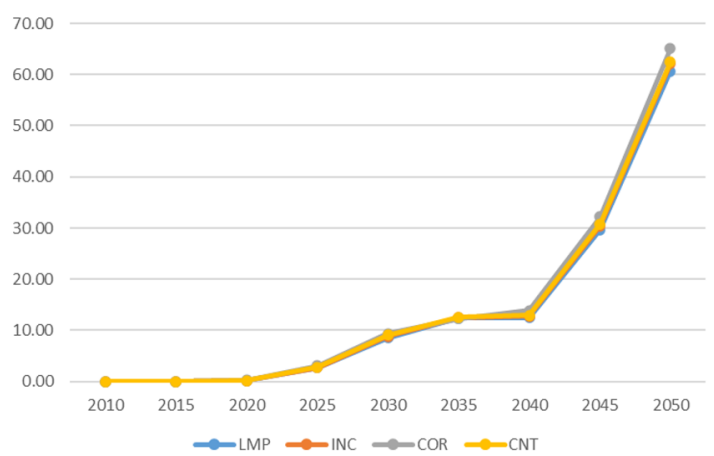

c) Net $\mathrm{CO} 2$ emissions (MtCO2)

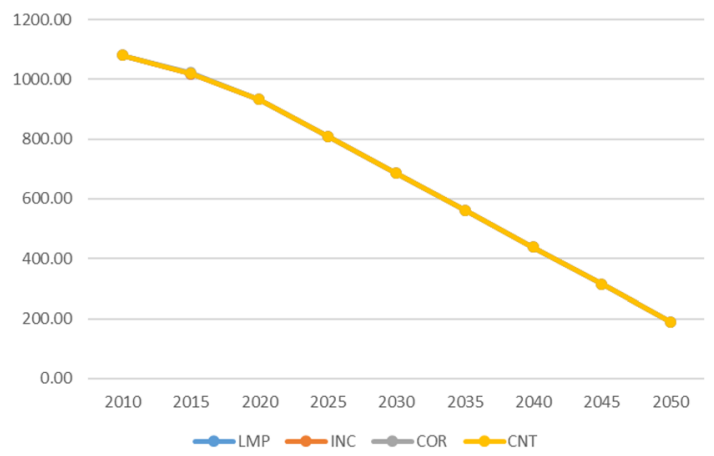

e) Tax level (BAU value=1)

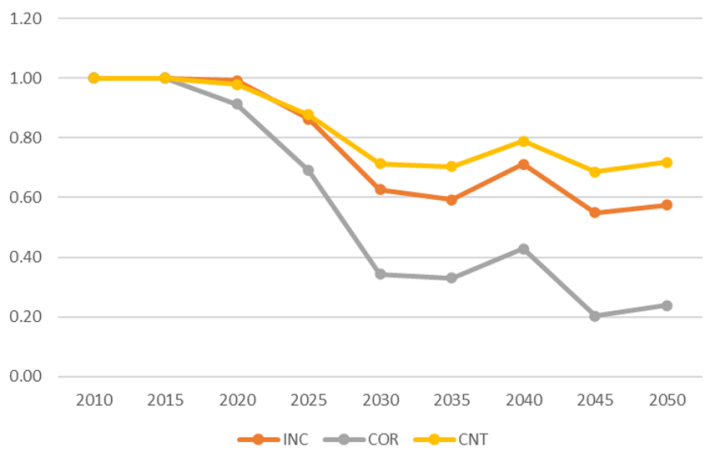

b) $\operatorname{CCS}(\mathrm{MtCO} 2)$

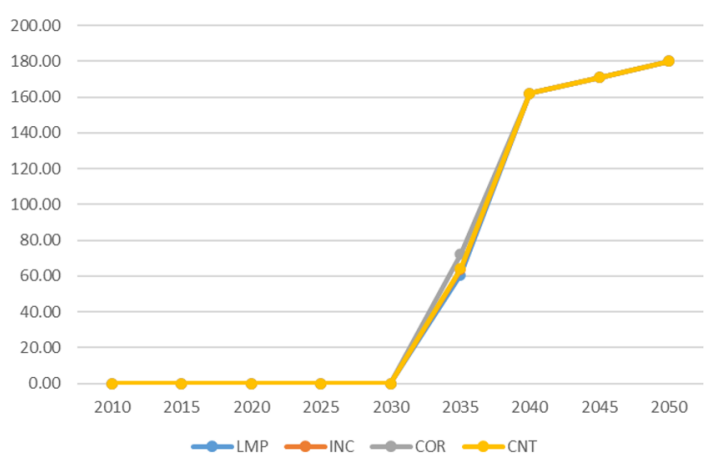

d) Carbon tax revenue (billion yen)

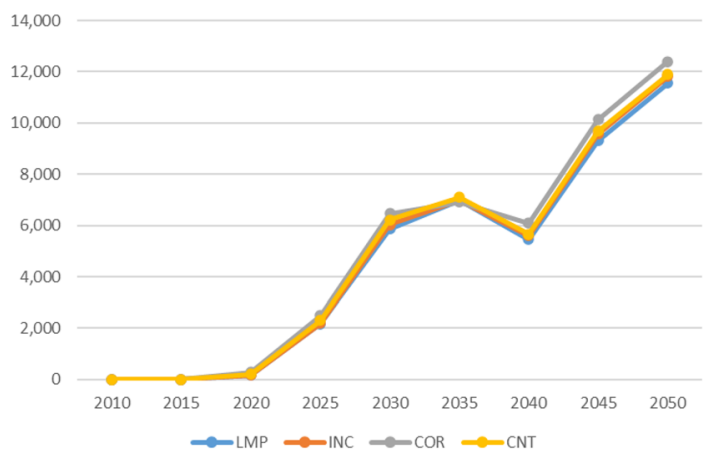

f) GDP

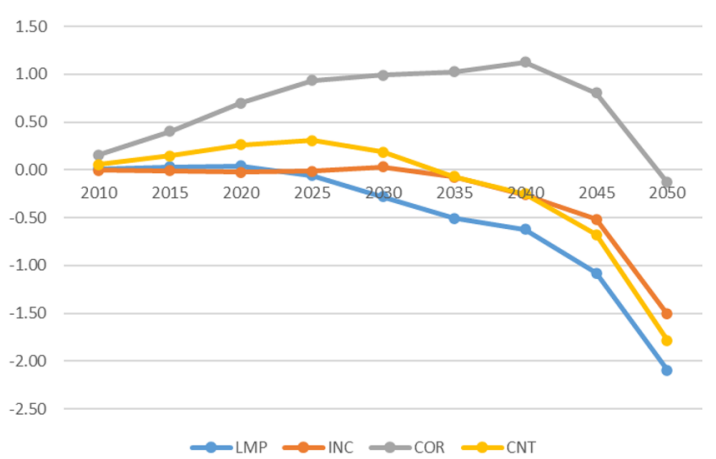

LMP is lump-sum rebate scenario, INC is income tax scenario, COR is corporate tax scenario and CNT is consumption tax scenario. All values are percentage change from BAU values unless otherwise indicated.

Fig. 9 Impacts on individual variables

in BAU eq.). Similarly, COR and CNT represent levels of corporate tax and consumption tax under corporate tax scenario and consumption tax scenario, respectively.

Finally, we would like to explain the mechanisms behind some of the results obtained so far. First, we only find a weak double dividend from some environmental tax reform scenarios. Although the revenue-recycling effect caused by the reduction in existing taxes works positively, the result without a strong double dividend means that the revenue-recycling effect is not strong enough to cancel out the negative impacts caused by the direct effect of the carbon tax and tax-interaction effect.

Compared to the cut in corporate tax, the cut in income tax and the cut in consumption tax have similar effects. One reason for this similarity may be the overlap between the tax bases of the two taxes. This is the well-known argument of "the equivalence between labor income and consumption taxes" (Atkinson and Stiglitz, 1976).

On the other hand, the cut in corporate tax increases GDP and income in 2030 and sum of their discounted values. This 
g) Income

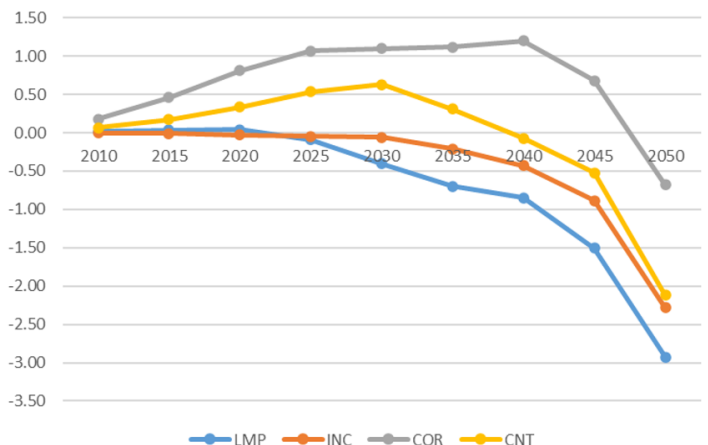

j) Consumption

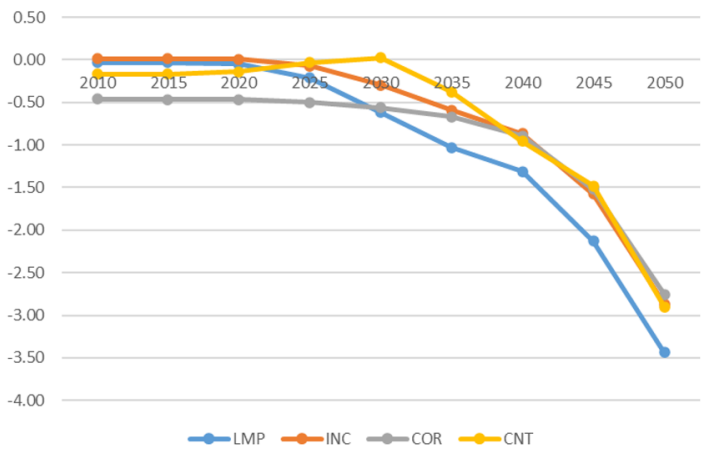

I) Labor supply

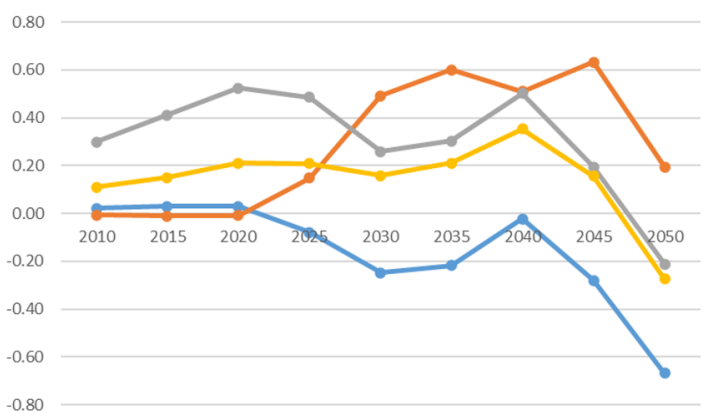

$\leadsto$ LMP $\leadsto$ INC $\multimap \mathrm{COR} \leadsto \mathrm{CNT}$ i) Period utility

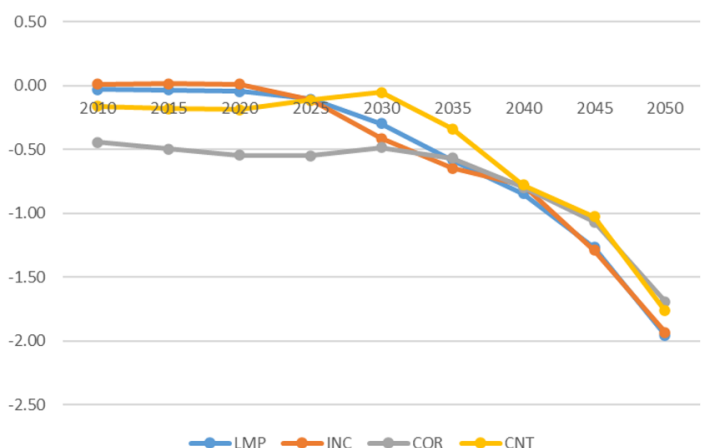

k) Investment

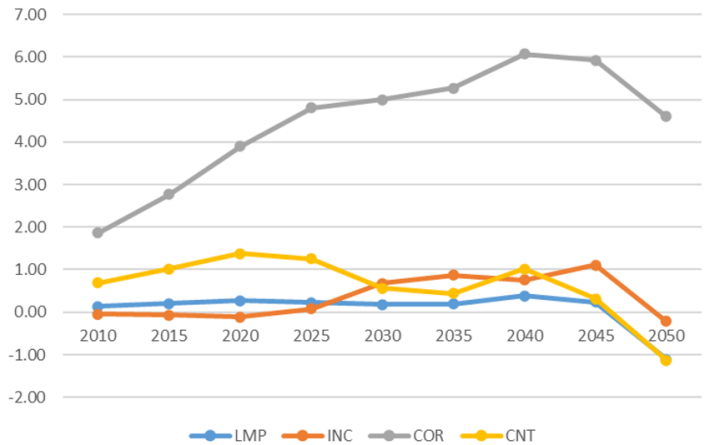

m) Leisure

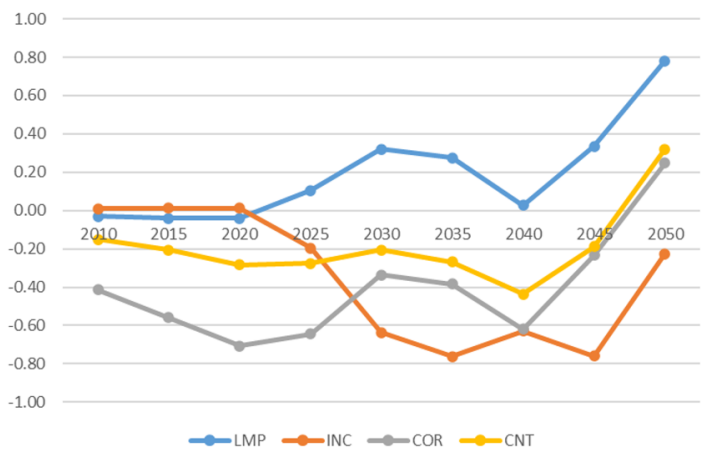

LMP is lump-sum rebate scenario, INC is income tax scenario, COR is corporate tax scenario and CNT is consumption tax scenario. All values are percentage change from BAU values unless otherwise indicated.

Fig. 9 (continued)

is because the cut in corporate tax strongly stimulates investment, which is shown in Fig. 9k. The increase in investment leads to the accumulation of capital stock, thus expanding production and income in the long run. Since this effect works strongly, the corporate tax cut scenario increases GDP and income.

However, at the same time, the cut in corporate tax is worse than the cut in income and consumption taxes in terms of (lifetime) utility. This is because increase in investment caused by the cut in corporate tax expands the decrease in consumption in the short-run which is shown in Fig. 9j, resulting in a large decrease in utility in the short-run. In addition, the cut in corporate tax expands the production and thereby increases the carbon tax rate required to achieve the reduction target. This leads to the rise in the marginal abatement cost of $\mathrm{CO}_{2}$, which has undesirable impact on utility. ${ }^{31}$

\footnotetext{
${ }^{31}$ It is well-known that marginal abatement cost of $\mathrm{CO}_{2}$ is equalized to carbon tax rate. It is because under carbon tax policy, those who emit $\mathrm{CO}_{2}$ reduce $\mathrm{CO}_{2}$ so that their marginal abatement cost of $\mathrm{CO}_{2}$ is equalized to carbon tax rate.
} 
Table 8 List of scenarios in the sensitivity analyses

\begin{tabular}{ll}
\hline Scenario & Explanation \\
\hline CCS_MORE & Scenario with more CCS \\
CCS_LESS & Scenario with less CCS \\
RENE_MORE & Scenario with more renewable energy \\
RENE_LESS & Scenario with less renewable energy \\
NUKE_MORE & Scenario with more nuclear energy \\
NUKE_LESS & Scenario with less nuclear energy \\
\hline
\end{tabular}

\section{Sensitivity analyses}

In the previous section, we have obtained several insights from the simulation. The simulation is based on specific assumptions and scenarios that are not necessarily realistic. To see how our results depend on the assumptions of the simulation and how changing the assumptions can change them, we conduct sensitivity analyses of the following aspects below: (1) the inclusion of CCS, (2) the inclusion of renewable energy, and (3) the inclusion of nuclear power. The list of sensitivity analyses is presented in Table 8 . The simulation conducted so far is referred to as the "benchmark simulation".

First, we change the amount of CCS because the amount of CCS available is highly uncertain. In the benchmark simulation, the upper limit of CCS is set to $180 \mathrm{MtCO}_{2}$. We change the limit on CCS to $200 \mathrm{MtCO}_{2}$ in CCS_MORE and to $160 \mathrm{MtCO}_{2}$ in CCS_LESS. Next, we change the amount of electricity generated by renewable energy because, as there is in CCS. In the benchmark simulation, electricity generated by renewable energy reaches approximately $230 \mathrm{TWh}$ in 2050 under the BAU scenario. We change the amount of resources used for electricity generation by renewables and thereby the amount of supply of electricity. Specifically, we increase electricity generated by renewables by $25 \%$ in RENE_MORE and decrease it by $25 \%$ in RENE_LESS.

Finally, we change the amount of electricity generated by nuclear power. After the Great East Japan Earthquake in 2011, many nuclear power plants have closed, and the supply of electricity from nuclear power remains low. Since the government has not provided a clear plan for future nuclear use, there is huge uncertainty in nuclear use in the future. Thus, we checked the sensitivity of nuclear use. In the benchmark simulation, electricity generated by nuclear power is set to approximately $100 \mathrm{TWh}$, which is basically constant over time. We increase electricity generated by nuclear by $50 \%$ in NUKE_MORE and decrease it by $90 \%$ in NUKE_LESS. Below, we check how the change in assumptions alters the results.

In the sensitivity analysis, we change one parameter for one scenario. For example, in NUKE_LESS scenario, we only change the amount of nuclear electricity. This approach means that BAU equilibrium in RENE_MORE/LESS and NUKE_MORE_LESS scenarios change from BAU equilibrium in the benchmark simulation. ${ }^{32}$ Since numerical values reported in Table 7 are percentage change from values in BAU equilibrium, we cannot directly compare scenarios with different BAU equilibrium.

Table 9 reports the simulation results of the sensitivity analyses. They show that we find at least a weak double dividend in many cases and a strong double dividend of GDP and income under some environmental tax reform scenarios. By changing assumptions, the quantitative impacts of the carbon tax often change to a large extent, but almost all qualitative insights derived from the benchmark simulation remain unchanged. It follows that the analyses in the previous sections have a certain level of robustness.

Note that the rate of increase in GDP in 2030 under the corporate tax scenario in CCS_LESS is larger than that in CCS_MORE. This may seem puzzling because the scenario with more restrictive capacity generates a more desirable impact on GDP. This is because the smaller CCS capacity leads to a higher carbon tax and thereby increases the value of carbon tax revenues, which in turn strengthen the revenue-recycle effect. ${ }^{33}$

\section{Conclusions}

Using a forward-looking dynamic computable general equilibrium model, we analyze the quantitative impacts of environmental tax reform and examine the validity of the double dividend hypothesis of the carbon tax by revenue recycling in the Japanese economy. As the emission reduction target, we chose the goal set by the Japanese government, i.e., the $80 \%$ reduction in $\mathrm{GHG}$ emission by 2050 . As environmental tax reforms, we examined the three types of revenue recycling of the carbon tax. The three scenarios we examined were the reduction in (1) income taxes, (2) corporate income taxes and (3) consumption taxes and compared these scenarios with the pure carbon tax (the carbon tax with a lump-sum rebate to households).

Our CGE simulations show that an environmental tax reform tends to generate more desirable impacts than the pure carbon tax. Environmental tax reform generates a strong double dividend in 2030 under many policy scenarios and at least a weak double dividend in 2050 in all scenarios, which indicates that the government should use

\footnotetext{
32 BAU equilibrium in CCS_MORE/LESS scenarios are the same as one in the benchmark simulation because CCS is active only in equilibrium with carbon tax.

${ }^{33}$ Note that, as explained before, we cannot compare RENE_MORE/ LESS and NUKE_MORE/LESS scenarios because they have different BAU equilibrium values.
} 
Table 9 Results of sensitivity analyses (\% change from BAU values) ${ }^{1}$

\begin{tabular}{|c|c|c|c|c|c|c|c|c|c|}
\hline & & \multicolumn{4}{|c|}{ CCS_MORE } & \multicolumn{4}{|l|}{ CCS_LESS } \\
\hline & & $\mathrm{LMP}^{2)}$ & INC & COR & CNT & LMP & INC & COR & $\mathrm{CNT}$ \\
\hline \multirow[t]{3}{*}{2030} & GDP & -0.30 & 0.02 & 0.85 & 0.14 & -0.27 & 0.03 & 1.15 & 0.24 \\
\hline & Income & -0.42 & -0.07 & 0.94 & 0.57 & -0.39 & -0.05 & 1.29 & 0.70 \\
\hline & Period util. & -0.29 & -0.41 & -0.42 & -0.03 & -0.31 & -0.42 & -0.57 & -0.08 \\
\hline \multirow[t]{7}{*}{2050} & GDP & -1.91 & -1.40 & -0.24 & -1.67 & -2.33 & -1.65 & -0.01 & -1.94 \\
\hline & Income & -2.63 & -2.06 & -0.72 & -1.98 & -3.29 & -2.55 & -0.66 & -2.31 \\
\hline & Period util. & -1.75 & -1.71 & -1.48 & -1.60 & -2.20 & -2.19 & -1.94 & -1.97 \\
\hline & Lifetime util. & -0.44 & -0.43 & -0.60 & -0.40 & -0.51 & -0.51 & -0.78 & -0.48 \\
\hline & Sum of discounted GDP & -0.48 & -0.25 & 0.54 & -0.21 & -0.52 & -0.27 & 0.80 & -0.17 \\
\hline & Sum of discounted income & -0.67 & -0.41 & 0.53 & -0.11 & -0.75 & -0.47 & 0.79 & -0.04 \\
\hline & & \multicolumn{4}{|c|}{ RENE_MORE } & \multicolumn{4}{|c|}{ RENE_LESS } \\
\hline \multirow[t]{3}{*}{2030} & GDP & -0.23 & 0.06 & 0.91 & 0.18 & -0.32 & 0.01 & 1.08 & 0.20 \\
\hline & Income & -0.34 & -0.02 & 1.01 & 0.58 & -0.45 & -0.09 & 1.20 & 0.68 \\
\hline & Period util. & -0.30 & -0.41 & -0.46 & -0.07 & -0.29 & -0.41 & -0.50 & -0.03 \\
\hline \multirow[t]{7}{*}{2050} & GDP & -1.99 & -1.44 & -0.31 & -1.82 & -2.21 & -1.57 & 0.06 & -1.76 \\
\hline & Income & -2.78 & -2.17 & -0.85 & -2.20 & -3.09 & -2.39 & -0.51 & -2.04 \\
\hline & Period util. & -1.91 & -1.89 & -1.65 & -1.73 & -2.00 & -1.97 & -1.74 & -1.80 \\
\hline & Lifetime util. & -0.47 & -0.47 & -0.65 & -0.42 & -0.47 & -0.46 & -0.72 & -0.44 \\
\hline & Sum of discounted GDP & -0.45 & -0.22 & 0.57 & -0.21 & -0.53 & -0.29 & 0.77 & -0.17 \\
\hline & Sum of discounted income & -0.65 & -0.39 & 0.55 & -0.11 & -0.75 & -0.48 & 0.77 & -0.03 \\
\hline & & \multicolumn{4}{|c|}{ NUKE_MORE } & \multicolumn{4}{|c|}{ NUKE_LESS } \\
\hline \multirow[t]{3}{*}{2030} & GDP & -0.19 & 0.07 & 0.96 & 0.23 & -0.32 & 0.10 & 1.19 & 0.24 \\
\hline & Income & -0.28 & 0.01 & 1.08 & 0.64 & -0.47 & 0.00 & 1.31 & 0.80 \\
\hline & Period util. & -0.24 & -0.33 & -0.42 & -0.03 & -0.37 & -0.52 & -0.54 & -0.03 \\
\hline \multirow[t]{6}{*}{2050} & GDP & -2.02 & -1.49 & -0.26 & -1.76 & -2.23 & -1.54 & 0.10 & -1.85 \\
\hline & Income & -2.80 & -2.21 & -0.79 & -2.11 & -3.17 & -2.42 & -0.52 & -2.19 \\
\hline & Period util. & -1.82 & -1.79 & -1.55 & -1.64 & -2.22 & -2.21 & -1.95 & -2.01 \\
\hline & Lifetime util. & -0.42 & -0.42 & -0.60 & -0.38 & -0.54 & -0.54 & -0.81 & -0.50 \\
\hline & Sum of discounted GDP & -0.46 & -0.25 & 0.58 & -0.19 & -0.51 & -0.23 & 0.87 & -0.15 \\
\hline & Sum of discounted income & -0.66 & -0.41 & 0.57 & -0.09 & -0.75 & -0.43 & 0.87 & 0.01 \\
\hline
\end{tabular}

${ }^{1}$ All values are percentage change from BAU value. The blue cells indicate a strong double dividend, and the orange cells indicate a weak double dividend

${ }^{2} \mathrm{LMP}$ is lump-sum rebate scenario, INC is income tax scenario, COR is corporate tax scenario and CNT is consumption tax scenario

environmental tax reform instead of the pure carbon tax. In particular, we found that the corporate tax cut is likely to generate the double dividend in terms of GDP and income. The corporate tax cut generates a strong double dividend of GDP and income in 2030 and sums of discounted GDP and income. Following our simulation results, the carbon tax with revenue recycling into corporate taxes may attract support from some stakeholders. The government may be able to obtain more public support for the carbon tax if 
they adopt the scenario of corporate tax reduction with revenue recycling.

However, our simulation results also have ambiguities. They show that an environmental tax reform does not always generate better impacts, and the existence of the double dividend can depend on the criteria and policy scenarios. For example, a corporate tax cut, which has the most desirable impact in terms of GDP and income, is not desirable in terms of (lifetime) utility. This ambiguous result implies that we need to continue a more elaborate analysis of environmental tax reform in the future.

In addition, in understating the implications of our simulation, some caution must be adopted because there are some limitations to our modeling. First, our model does not incorporate more efficient alternatives to existing fossil fuel-based and carbon inefficient technologies. For example, we do not model hydrogen fuel, which is an important energy source to realize decarbonization. The diffusion of hydrogen fuel may not be relevant in 2030 but is expected to be crucial in 2050. Furthermore, we do not model the transportation sector in a sophisticated manner. Thus, electric vehicles or fuel cell vehicles that make use of hydrogen fuel are not captured in detail.

Third, our approach for modeling taxes has some problems. The actual income tax in Japan is a progressive tax and the tax rate changes depend on income classes. However, we cannot consider the progressive nature of income tax because we use a representative household assumption. The actual corporate tax has different tax rates for firms with different sizes, but we do not consider multiple rates in corporate tax system. The consumption tax after 2019 has two tax rates, i.e., the standard tax rate and the reduced rate. However, we assume one uniform tax rate. Our approach for modeling the tax system in Japan has many problems that need to be improved. These aspects of the modeling are areas for future research. With these revisions in the modeling, we will be able to understand the possibilities of the double dividend in 2050 more accurately.

Supplementary Information The online version contains supplementary material available at https://doi.org/10.1007/s11625-021-00903-4.

Acknowledgements We appreciate comments from Kanemi Ban, Akira Yokoyama, Kiyoshi Fujikawa, Makoto Sugino, Soocheol Lee and Seung-Joon Park. We are also grateful for the administrative support provided by Yukie Iwatsuka. This research was supported by the Environment Research and Technology Development Fund (JPMEERF20172007 and JPMEERF20202008) of the Environmental Restoration and Conservation Agency and JSPS KAKENHI Grant Number JP18K01633. We also appreciate the financial support from the Foundation of Japanese Bankers.

Open Access This article is licensed under a Creative Commons Attribution 4.0 International License, which permits use, sharing, adaptation, distribution and reproduction in any medium or format, as long as you give appropriate credit to the original author(s) and the source, provide a link to the Creative Commons licence, and indicate if changes were made. The images or other third party material in this article are included in the article's Creative Commons licence, unless indicated otherwise in a credit line to the material. If material is not included in the article's Creative Commons licence and your intended use is not permitted by statutory regulation or exceeds the permitted use, you will need to obtain permission directly from the copyright holder. To view a copy of this licence, visit http://creativecommons.org/licenses/by/4.0/.

\section{References}

Akimoto K, Sano F (2017) Analyses on Japan's GHG emission reduction target for 2050 in light of the $2{ }^{\circ} \mathrm{C}$ target stipulated in the paris agreement. J Jpn Soc Energy Resou 38:1-9 https://doi. org/10.24778/jjser.38.1_1

Arimura TH, Abe T (2020) The impact of the Tokyo emissions trading scheme on office buildings: what factor contributed to the emission reduction? Environ Econ Policy Stud. https://doi. org/10.1007/s10018-020-00271-w

Arimura TH, Kaneko S, Managi S, Shinkuma T, Yamamoto M, Yoshida Y (2019) Political economy of voluntary approaches: a lesson from environmental policies in Japan. Econ Anal Policy 64:41-53. https://doi.org/10.1016/j.eap.2019.07.003

Armington PS (1969) A theory of demand for products distinguished by place of production.

Atkinson AB, Stiglitz JE (1976) The design of tax structure: direct versus indirect taxation. J Pub Econ 6:55-75. https://doi. org/10.1016/0047-2727(76)90041-4

Babiker MH, Gurgel AC, Paltsev SV, Reilly JM (2009) Forwardlooking versus recursive-dynamic modeling in climate policy analysis: a comparison. Econ Model 26:1341-1354. https://doi. org/10.1016/j.econmod.2009.06.009

Bernstein PM, Montgomery WD, Rutherford TF (1999) Global impacts of the kyoto agreement: results from the MS-MRT model. Resou Energy Econ 21:375-413. https://doi.org/10.1016/S0928 -7655(99)00009-3

Bovenberg AL, Goulder LH (2002) Environmental taxation and regulation. In: Auerbach AJ, Feldstein M (eds) Handbook of public economics. Elsevier, Amsterdam, pp 1471-1545

Bovenberg AL, van der Ploeg F (1998) Consequences of environmental tax reform for unemployment and welfare. Environ Resour Econ 12:137-150. https://doi.org/10.1023/A:1016040327622

Capros P, Van Regemorter D, Paroussos L, Karkatsoulis P, Fragkiadakis C, Tsani S, Charalampidis I, Revesz T, Perry M, Abrell J, Ciscar MJC, Pycroft J, Saveyn B (2013) GEM-E3 Model Documentation

Carbone JC, Morgenstern RD, Williams RCI, Burtraw D (2013) Deficit reduction and carbon taxes: budgetary, economic, and distributional impacts. Considering a carbon tax: a publication series from RFF's Center for climate and electricity policy

Center for Global Environmental Research (2018) Embodied energy and emission intensity data for Japan 2011 using input-output tables (3EID).

Chateau J, Dellink R, Lanzi E (2014) An overview of the OECD ENVlinkages model: version 3. OECD Environment Working Papers, No. 65 43. https://doi.org/10.1787/5jz2qck2b2vd-en

Chen Y-HH, Paltsev S, Reilly J, Morris J, Babiker MH, (2015) The MIT EPPA6 Model: economic growth, energy use, emissions, and food consumptions 40

Diao X, Thurlow J (2012) A recursive dynamic computable general equilibrium model. In: Diao X, Thurlow J, Benin S, Fan S (Eds) Strategies and priorities for african agriculture: economywide perspectives from country studies. International Food Policy 
Research Institute (IFPRI), Washington, D.C., pp. 17-50. https ://doi.org/10.2499/9780896291959

Freire-González J (2017) Environmental taxation and the double dividend hypothesis in CGE modelling literature: a critical review. J Pol Model. https://doi.org/10.1016/j.jpolmod.2017.11.002

Goulder LH (1995) Environmental taxation and the 'Double Dividend': a reader's guide. Int Tax Public Fin 2:157-183

Hamamoto M (2020) Impact of the Saitama Prefecture target-setting emissions trading program on the adoption of low-carbon technology. Environ Econ Policy Stud. https://doi.org/10.1007/s1001 8-020-00270-x

International Energy Agency (2018) World Energy Outlook 2018, World Energy Outlook. OECD. https://doi.org/10.1787/ weo-2018-en

Jorgenson DW, Goettle RJ, Ho MS, Wilcoxen PJ (2013) Double dividend: environmental taxes and fiscal reform in the US, 1st edn. The MIT Press, Cambridge

Lau MI, Pahlke A, Rutherford TF (2002) Approximating infinite-horizon models in a complementarity format: a primer in dynamic general equilibrium analysis. J Econ Dyn Control 26:577-609

Lee S, Pollitt H, Park S-J (Eds) (2016) Low-carbon, sustainable future in East Asia: improving energy systems, taxation and policy cooperation, Routledge studies in the modern world economy. Routledge, Taylor \& Francis Group, London, New York.

Lofgren H, Harris RL, Robinson S (2002) A standard computable general equilibrium (CGE) model in GAMS. International Food Policy Research Institute (IFPRI), Washington, D.C.

Ministry of Environment (2012) Details of Carbon Tax, https://www. env.go.jp/en/policy/tax/env-tax/20121001a_dct.pdf.

Ministry of Internal Affairs and Communications Japan (2016) Inputoutput tables for Japan 2011. Ministry of Internal Affairs and Communications Japan
Paltsev SV, Reilly JM, Jacoby HD, Eckaus RS, Mcfarland JR, Sarofim M, Asadoorian M, Babiker MH (2005) The MIT emissions prediction and policy analysis (EPPA) Model: Version 4. MIT Joint Program on the Science and Policy of Global Change

Pereira AM, Pereira RM, Rodrigues PG (2016) A new carbon tax in Portugal: a missed opportunity to achieve the triple dividend? Energy Policy 93:110-118. https://doi.org/10.1016/j.enpol .2016 .03 .002

Policy Research Institute (2012) Ministry of Finance statistics monthly No.722. Policy Research Institute, Ministry of Finance, Japan.

Saveyn B, Van Regemorter D, Ciscar JC (2011) Economic analysis of the climate pledges of the Copenhagen Accord for the EU and other major countries. Energy Econ 33:S34-S40. https://doi. org/10.1016/j.eneco.2011.07.024

Sugiyama M, Fujimori S, Wada K, Oshiro K, Kato E, Komiyama R, Heran DS, Matuo Y (2020) The EMF 35 JMIP study for Japan's long-term climate and energy policy: Scenario design and key findings.

Takeda S (2007) The double dividend from carbon regulations in Japan. J Jpn Int Econ. https://doi.org/10.1016/j.jjie.2006.01.002

Takeda S, Kawasaki Y, Ochiai K, Ban K (2010) An analysis of the medium-term target for $\mathrm{CO} 2$ reduction by the JCER-CGE model. Rev Environ Econ Pol Stud (Kankyo Keizai Seisaku Kenkyu) 3:31-42 ((In Japanese))

Takeda S (2006) A supplement to "the Double Dividend from Carbon Regulations in Japan.” https://shirotakeda.org/en/research/ dd-carbon.html

Publisher's Note Springer Nature remains neutral with regard to jurisdictional claims in published maps and institutional affiliations. 